\title{
Anti-Violence Education Through Electronic Media and Parent Supervision for Early Childhood in the Perspective of Psychology
}

\author{
Yorita Febry Lismanda, Mutiara Sari Dewi, I ka Anggraheni \\ Received: 29102016 / Accepted: 29102016 / Published online: 13122016 \\ ๑ 2016 Association of Indonesian Islamic Kindergarten Teachers Education Study Program
}

\begin{abstract}
Abstrak Anak usia 4-6 tahun berada pada tahap pra operasional konkrit. Stimulus negatif yang diperoleh anak pada masa itu, membentuk sikap anak di masa yang akan datang. Adanya tontonan TV, games, dan video yang mengandung tindak kekerasan merupakan bentuk stimulus negatif. Data KPAI menunjukkan 78,3\% anak usia MI hingga SM A melakukan kekerasan. Salah satu faktor yang menyebabkan, dimungkinkan adanya stimulus negatif yang diperoleh anak sejak dini. Pendekatan yang digunakan dalam prosiding ini adalah pendekatan kualitatif. Data berupa fakta banyaknya kekerasan yang dilakukan anak, tontonan di TV, games, dan video yang mengandung unsur kekerasan, tahapan perkembangan anak, dan dampak dari tontonan. Data tersebut diambil melalui studi pustaka dari beberapa referensi yang dianalisis dan hasilnya disampaikan secara deskriptif. Simpulannya adalah bahwa faktor penyebab anak menjadi pelaku kekerasan berasal dari tontontan yang mengandung tindak kekerasan dan ditiru anak sejak dini. Cara mengatasi anak yang melakukan kekerasan adalah dengan pemberian tontonan pada media elektronik yang banyak mengandung nilai edukasi dan diperkuat adanya pengawasan orang dewasa terdekatnya, khususnya orang tua sejak anak dalam usia dini.
\end{abstract}

Kata kunci: kekerasan usia 4-6 tahun, media elektronik, pengawasan.

\begin{abstract}
Children of 4-6 years are in concrete pre-operational stage. N egative Stimulus obtained by a child at that time, forming attitudes of children in the future. TV shows, games, and videos containing violence are form of negative stimulus. KPAI data showed $78.3 \%$ of children aged elementary school to senior high school have undertaken such violence. One of the factors is possibly the existence of negative stimulus acquired since early childhood. The approach used in this proceeding is a qualitative approach. Data was taken from the fact of a numbers violence that have been undertaken by children, TV shows, games, and videos containing elements of violence, stages of child development, and the impact of the show. The data was retrieved through library research of several references that were analyzed and the results were presented descriptively. The conclusion is the causing factor that lead children to become abusers come from TV's program containing violence and imitated since early childhood. How to cope with children who commit in violent is by giving TV shows of electronic media containing a lot of educational value and strengthened them with their close relative supervision, especially parents since the children in early age.
\end{abstract}

Keywords violence aged 4-6 years, el ectronic media, supervision. 


\section{Introduction}

Early childhood period is the first period which determined the children' life to the next periods. At present, almost all what children see and hear from surroundings takes a role as stimulus for their development. Saparno (2015:56) stated that one of characteristics in milestone of early childhood, especially children of 4-6 years is the ability to cope any responses they see and hear. If the stimulus is positive, the chance to develop based on their milestone is bigger, and the opposite.

One of negative stimulus which broadly discussed is the lack of moral, ethic, and educative value of TV shows watched by children. Its impact is the increase of violence which involves early childhood as the subject. KPAI's data in 2012 (Pranawati, 2014) showed that 78.3 percent of 1026 students from Madrasah Ibtidaiyah to Senior High School in Indonesia become the subjects of violence. $O$ ne of the factors which causes it is possibly the availability of negative stimulus obtained by early childhood.

TV shows, games, hand-phone, pad, or computer with the internet access are the factors which have a wide influence toward the character building of children. Temkin, Deborah (2015) stated that "Television and other media can contribute to the development of both aggression and pro-social skills". The statement above was agreed by Susanto, the vice of KPAI (in Kabar 24, 2016). He said that children becoming the subject of violence is because of the negative effect of film or video game which contains violence. Through those media, children is accustomed to the violence. It is getting worst by the lack of control and supervision from parents toward their children anytime their children access the internet or play the games from their hand phone, pad, and computer.

Early childhood periods easily copes everything without proper supports of what they are watching toward their development and the lack of control and supervision, it has resulted children doing the similar violence against their friends. Children of 4-6 years do the violence because of coping, it is not because of themselves. However, parents could not let it or underestimate it. A little thing is the beginning of their future. Based on the explanation above, this proceeding will discuss the alternative method to overcome the violence since children aged 4-6 years through psychology perspective.

\section{Electronic media as ante corruption education}

The violence by which early childhood as the subject is not something unfamiliar for the last decades. As the previous explanation, it was said that the milestone of children aged 4-6 years provided the ease to do violence started from coping period.

Suparno (2001:56) said that one of the characteristic in the milestone for children of 4-6 years is the ability to cope everything they see and hear. That statement is in line with Asmawati statement(2010:19), she said that one of the characteristic of the child development period is coping period. Coping period for children is the beginning period for them. Jean Piaget confirmed that early childhood view everything based on their own view, their understanding 
concept is still unpolished, and their thought is still in pre-concept (in Asmawati, 2014:24). The heteronomous moral development of early childhood is because their brain does not develop perfectly yet. So that they do not have thinking maturity.

With the result that when early childhood undertake bullying, they do not do it purposefully but they do it as they do not know how to act in a good manner based on the norm applied in their society. According to the milestone of early childhood, it is clear that violence has been done by children aged 4-5 years does not come from themselves but it is the result of coping. In this period, they easily cope some scenes they watch on and begin to practice it against their friends. They are not aware that those are violence.

In addition to the period, their emotional development is also easily affected. Seefeldt (2008:69) said that the emotional condition of children depends much on their surroundings and always change as soon as they move on another activity. This could trigger violence in which they are as subject after playing games.

The contents of the games they play and their unstable emotion when they play games become the source for them to release their disappointment or their sadness as it is shown in media. For them, it is only spontaneous activity in which they really do not know the impact whether it is good or bad.

The milestone of 4-6 years children which is in active period to receive any stimulus from surroundings and it is not supported by parents' control takes a role in causing violence. Parents and family are the closest relatives for children, who contribute toward the child development. Bronfenbrenner (in Harvard Family Research Project, 2006) stated that the family seems to be the most effective and economical system for fostering and sustaining the child's development. in term of the child's emotional development, Thompson (in Santrock, 2007) also said that parents are the parties that are able to control the child's emotion. The statement explicitly explained the role of family especially parents because of their important role of the child's development.

Each TV shows, video, or any other negative contents of the games or computer without parents' control will easily damage the child's development. Unconsciously, children will practice what they have seen in the form of violence. UU No. 35 year 2014 about children care stated that violence is any activity against children causing suffering or infliction physically, psychologically, sexuality or any other form of neglecting include of threat to behave, force or despoil their independence against the legal law. Based on that statement, it could be said that children behavior such as mocking, pushing, or bullying, if it is done many times it can cause the existed of violence.

M ocking, pushing and bullying for early childhood often happened. It is usually because of their egocentric period that is still high. Piaget (in Slavin, 2011:45) said that children of 4-6 years are in pre operational, it means children are egocentric and self centered. However, it is not supposed as the normal thing. The current development which is more modern, has broadened the possibility to get influence from what they see so that the act of bullying can be aware as early as possible. 
Negative content as seen in Naruto, Boi boi boy, Spongebob and video shows which they access through internet containing violence is easily coped by children. Pranawati (2014) stated that our TV shows is not worthy for watching. It is also not suitable for their ages whether the actors, the stories, or the visualization. The violence shown is ordinary, common and natural to cope. Below is an example the show contains violence.

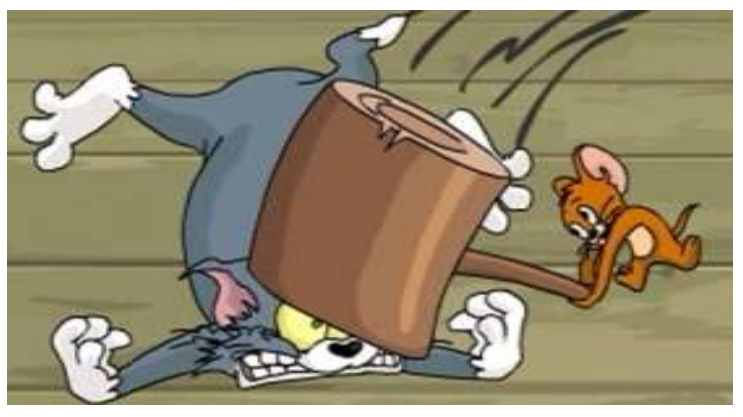

Figure 1.

Cartoon film contains violence (Source: http://google.com, retrieved on A pril 25, 2016)

Children of 4-6 years also play games that blow up their negative emotion, moreover when they fall off the games. The example of the games with its big impact toward child's emotion are:

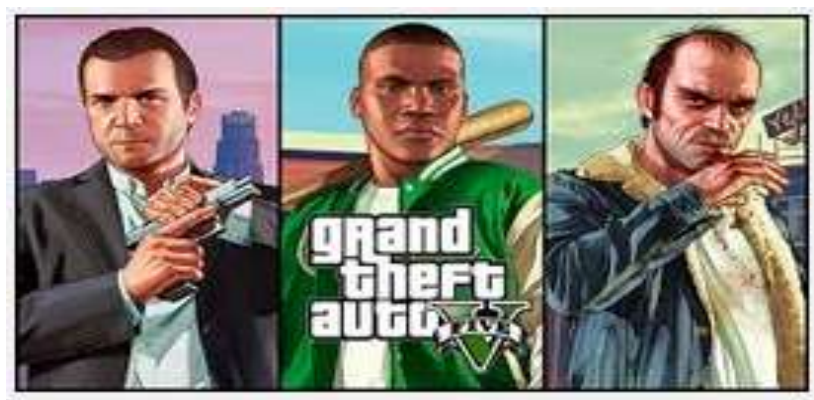

Figure 2.

Games with its big influence toward children emotion of 4-6 years (Source: http://google.com, retrieved on April 25, 2016)

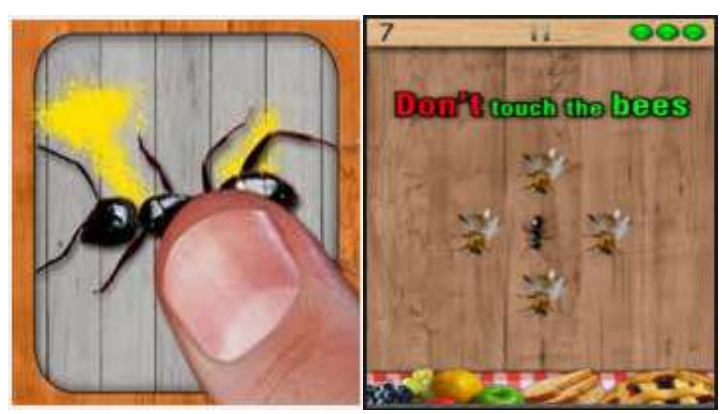

Figure 3.

Games with its big influence toward children emotion of 4-6 years (Source: http://google.com, retrieved on April 25, 2016)

Games in figure 2 does not only affect the children' emotion but also contains the violence. 
While games in figure 3affects children emotion when they play it mainly when they have to push the ant motion till it dies or when they fail to complete it.

Unimportant thing begin to trigger the subject to do violence against early childhood or teenager. This, of course would increase the number of victims against children. NAEYC's data reported by V lachous (in Snow, 2014: 1) The report study of 4-years-old showing 25\% of children as bullies and 22\%. The data then strengthened by KPAI's data in 2012 (Pranawati, 2014) as follows:

Graphic 1.

The reality and the data of violence against children in Indonesia

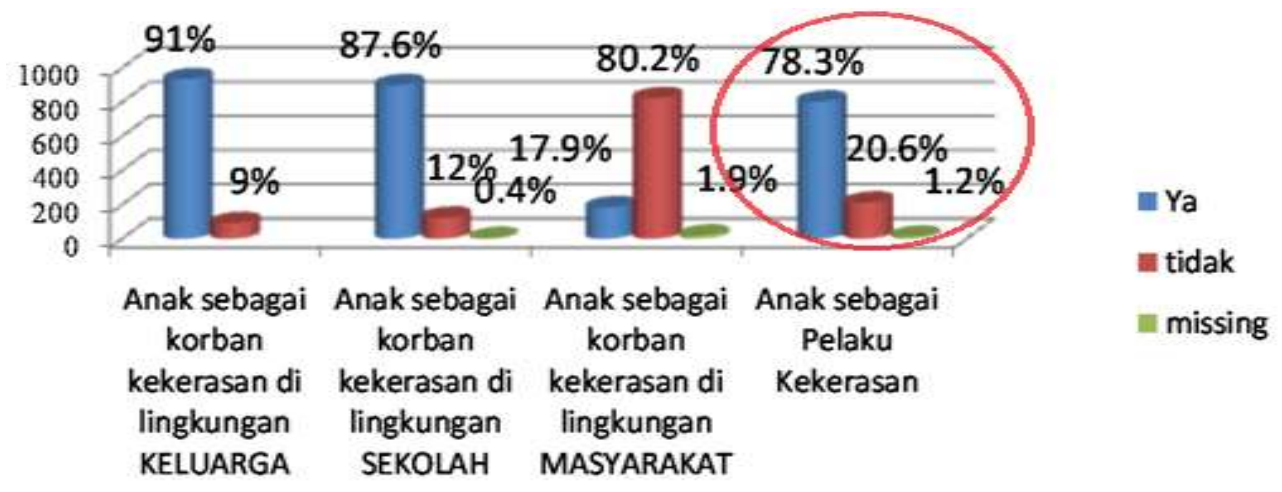

From the data above, it can be explained that 78.3 percent children aged MI to Senior High School become the subject and 20.6 percent admitted they never become the subject. It perhaps they are used to watching the violence since they were 4-6 years old. A nother supporting data obtained from the similar research as follows:

Graphic 2.

The type of violence against children.

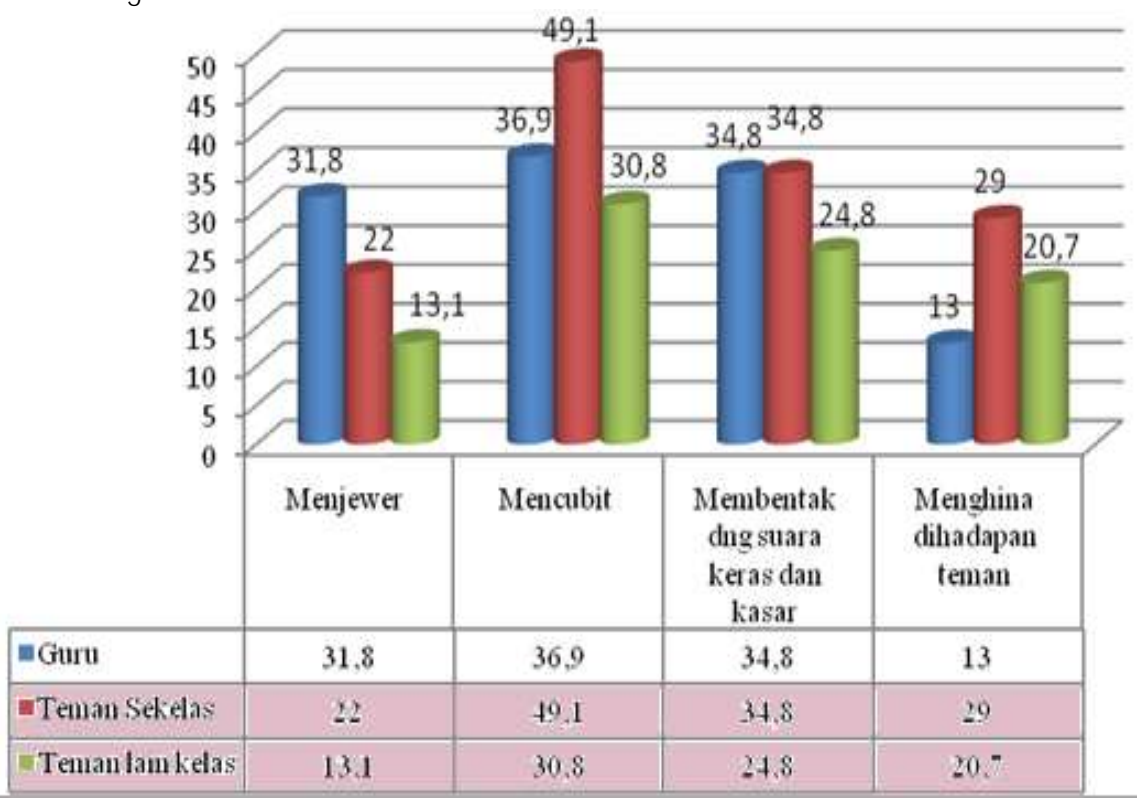

From the data above, the subject of violence could be by tweaking, pinching, shouting 
loudly or insulting in front of their friend is mostly their classmates or the other class, it was 50 percent. While 45.1 percent of the subject is just tweaking, 79.9 percent is pinching, 58.8 percent is shouting loudly, and 49.7 percent is insulting in front their friend.

Those explanations above show that in early childhood period especially children of 4-6 years become prolific target of the violence development. This prolific target must be used as the beginning to overcome the violence as ante violence education toward early childhood. Below is the alternative proceeding in how to overcome violence has been done by early childhood based on the psychology proceeding, TV's shows watched by children, games, video and parents control.

The first method could be discussed from the perspective of psychology with the morality building. Moral building for early childhood is very significant to do as education has strategic role to introduce the concept of life reflected moral value. Without education principals, children morality will be under controlled by their biological need only when they decide everything. M orality education is as the part of ante violence education toward early childhood.

A nte violence education which is seen from psychology perspective, mainly related to two thing which is inter-correlated, they are morality development and cognitive development. According to John Dewey (in Hidayat, 2009:15), early childhood (0-6 years old) is in the pre-morality periods. They do not recognize the concept of morality and their behaviors are mostly based on their biological impulse and their surroundings. Morality education can be achieved through parents control and supervision when children are accessing games and video. The real example for this case is when a child is lack of control and supervision from his/her parents so the environment has a much role in his/her life, he/she will not only waste his/her time by watching TV and video but also playing games.

Finally, if we let it happen all the times so electronic media which contains violence values will automatically affect their biological impulse as like the explosive temper tantrum, spoken rudely, and beating other. Jean Piaget placed the morality development of early childhood in heteronomous period (2-7 years old) (in Hidayat, 2009:16). In this period children still can not distinguish between good and bad and can not be able to determine their choice toward their behavior. The real example is an early child who does bullying for the first unconsciously , that he/she will consider that his/her behavior is good and he will repeat it to the next so it becomes habit. It is opposite to autonomous period (over 7 years old). Who does bullying for the first consciously, he/she will feel guilty because he/she comprehends that it is as bad behavior. Thus, it is shown that morality building for early childhood really affected by their environment. Where the environment is comfortable, appreciates each other, and has a well brotherhood, it will create a good personality and politeness toward children behavior. On the contrary, where the environment is full of violence, rivalry, and has no good manner in socializing, it will create a nasty personality in their early living. It is such as the habit of bullying physically, verbally or symbolic manner.

The fact of 78. 3 percent, children of MI to Senior high School in Indonesia perpetrate 
violence which is seen from Piaget's theory perspective as explained previously, it has been known that since early childhood, MI children have become accustomed to do violence. It is because their thinking development periods of pre-operational by which children of 4-6 years are still not able to distinguish between good and bad toward their attitudes. They had better receive better learning experience stimulation but on the other way, they receive worse learning experience so that it becomes their habits. It is strengthened by their egocentric period since early childhood and continues to the future.

Thus, it is needed an education shows as the solution to overcome the effect of shows containing violence values so that the positive effect for early childhood can increase. Ante violence education for early childhood, in the form of education shows and parents' control and supervision is aimed in order early childhood will cope the good behavior based on their idol roles watched on TV, games and video.

Children who watch on the shows containing violence continuously without parents' supervision can cause dissonance, it is the decrease of moral value of someone (H idayat, 2009: 35). This is because children with their habits in watching video or TV and playing games containing violence but their parents never admonish them, it will lead children to have negative habit (bullying), and they also do not have guilty feeling.

Through presenting an education electronic media (TV, video, and games) and parents' supervision, it hopes early childhood are able to learn morality concept joyfully. An education electronic media will be able to build cognitive motivation aspect of early childhood for the next. It is the basic orientation which underlies someone's consideration against the risk appears if he/she has undertaken something. (Peter in Hidayat, 2009:14) according to that, it can be realized that children behave in their daily life is under lied by the cognitive motivation concept. If their cognitive motivation regards that violence is not something worst and they do not need to feel guilty so they will often do it again and again. When early childhood begin recognizing morality concept better and have good cognitive motivation related to expected behavior is the behavior which follow the norm, so in their daily life they have accustomed to behave politely and in good manners. Finally, by giving an education electronic media and parents' control and supervision increase positive effect toward children' character building and the subject of violence can be reduced.

\section{Conclusion}

The causing factor children become the subject of violence comes from electronic media (games, videos and TV) which they have watched and they cope in their daily life since early childhood. That was supported by children milestone as the prosperous target for any kinds of stimulus from what they see and hear.

To overcome this is by giving shows on electronic media (games, videos and TV) that is worth for watching and contains education value. Furthermore it is strengthened by parents' control and supervision since early childhood. 


\section{References}

Asmawati, Luluk. 2010. Pengelolaan Kegiatan Pengembangan Anak Usia Dini. Jakarta: Universitas Terbuka.

Hidayat, Otib. 2009. M etode Pengembangan Moral dan Nilai-nilai Agama. Jakarta: Universitas Terbuka.

Pranawati, Rita. 2014. Kekerasan Pada Anak dan Aspek Kuratif. (H andout Seminar). Yogjakarta:

Santrock, J.W. 2007. Psikologi Pendidikan (edisi kedua). (Penerj. Tri Wibowo B.S). Jakarta: Kencana.

Seefeldt dan Wasik. 2008. Pendidikan Anak Usia Dini: Menyiapkan Anak Usia Tiga, Empat, dan Lima Tahun M asuk Sekolah. Jakarta: PT. Indeks.

Slavin, Robert. 2011. Psikologi Pendidikan: Teori dan Praktik. Jakarta: Indeks.

Snow, Kyle. 2014. Bullying in Early Childhood Education. Washington, DC: NAEYC.

Suparno Paul. 2001. Teori Perkembangan Kognitif Jean Piaget. Yogjakarta: Kanisius.

Susanto. 2016. KPAl: Faktor Lingkungan Picu Kekerasan Anak (Online) http://kabar24.bisnis.com/read/20160321/79/530241/kpai-faktor-lingkungan-picu-kekera san-anak diakses tanggal 25 A pril 2016.

Temkin, Deborah. 2015. To Prevent Bullying, Focus On Early Childhood. Washington, DC: NAEYC.

. 2006. Family Involvement in Early Childhood Education (Harvard Family Research Project). Cambridge: H arvard

. 2014. Undang-Undang Republik Indonesia Nomor 35: Tentang Perlindungan Anak. Jakarta: -. 